\title{
ANALISIS PERBANDINGAN KURVA HAZARD PADA KABUPATEN RAJA AMPAT (PULAU WAIGEO) DENGAN SUMBER GEMPA SESAR SEULIMEUM DAN MENGGUNAKAN BEBERAPA FUNGSI ATENUASI ATENUASI Mc Guire (1977), Cornel 1979, Cambell, 1990 dan Ambraseys (1995)
}

\author{
Wahyu A.P Mouko') , Surya E.S Fabanyo') , Novri L. Maspaitella ${ }^{3)}$ FifI S. Macpal ${ }^{4)}$ \\ 1),2),3),4)Program Studi Teknik Sipil, Universitas Muhammadiyah \\ Waisai (Pulau Waigeo) \\ Email : phutrawahyumouko@gmail.com
}

\begin{abstract}
Abstrak
Kabupaten Raja Ampat merupakan daerah yang rawan terhadap gempa bumi karena terdapat zona subduksi dan sesar di daerah tersebut. Salah satu sesar yang melewati daerah tersebut adalah sesar Seulimeum. Sesar ini membentang sepanjang $122 \mathrm{~km}$ di daratan pulau Papua. Ancaman gempa bumi dari sesar ini tentunya dapat membahayakan daerah sekitar. Pada penelitian ini melakukan analisis kurva hazard untuk mengetahui berapa besar percepatan tanah (ground acceleration) yang terjadi akibat gempa bumi pada wilayah ini dengan berbagai macam kala ulang (return period). Probabilitas terlampaui yang digunakan adalah $10 \%$ dengan umur rencana 50 tahun. Kurva hazard dianalisis menggunakan fungsi atenuasi Donovan (1972), fungsi atenuasi Esteva (1972), fungsi atenuasi Cornel (1979), Campbell (1990), dan Xiang \& Gao (1994). Hasil penelitian menunjukkan besarnya nilai percepatan tanah (ground acceleration) akan meningkat seiring dengan besarnya nilai kala ulang (return period) yang diperhitungkan. Kurva hazard pada daerah Waisai (Pulau Waigeo) akibat sesar Seulimeum akan menunjukkan nilai terbesar pada saat menggunakan fungsi atenuasi Donovan (1972) sedangkan yang terkecil adalah menggunakan fungsi atenuasi Esteva (1972).
\end{abstract}

Kata Kunci : Kurva Hazard, Atenuasi, Sesar Seulimeum, Kota Waisai (Pulau Waigeo)

\section{Pendahuluan}

Pulau Papua terletak di sebelah Timur wilayah negara Indonesia. Resiko gempa pada wilayah ini tergolong tinggi. Hal ini disebabkan sepanjang pulau Papua terdapat zona subduksi yang lokasinya sejajar dengan garis pantai. Selain itu, pada daratan pulau Papua terdapat sesar yang terbagi kedalam beberapa segmen. Setidaknya terdapat 19 segmen pada wilayah ini. Salah satu segmen sesar yaitu seulimeum. Sesar seulimeum memiliki Panjang sekitar $122 \mathrm{~km}$ yang tentunya ini merupakan zona bahaya terhadap daerah sekitar sesar ini.

Kota Waisai (Pulau Waigeo) merupakan salah satu kota yang terletak dekat dengan sesar seulimeum. Lokasi ini tentunya sangat berpotensi terhadap ancaman gempa yang bersumber pada sesar tersebut. Kejadian gempa bumi memiliki kala ulang (return period). Semakin besar kala ulang (return period) yang diperhitungkan maka resiko ancaman bahaya akan semakin besar juga.

Salah satu parameter yang diperhitungkan dalam analisis struktur gedung tahan gempa adalah percepatan tanah yang terjadi pada saat gempa bumi.

Data ini sangat penting diketahui mengingat frekuensi gempa di daerah pulau Papua terkhususnya kota Waisai (Pulau Waigeo) sangat sering terjadi.

Kurva hazard adalah suatu grafik yang menunjukkan hubungan antara percepatan tanah (ground acceleration) terhadap kala ulang (return period) dari suatu gempa bumi. Dengan menganalisis kurva ini maka dapat diperoleh nilai besaran percepatan tanah pada setiap kala ulang tertentu yang terjadi pada suatu wilayah.

Besarnya percepatan tanah tidak hanya dipengaruhi oleh magnitudo dan jarak gempa dari episenter. Namun terdapat pengaruh lain yaitu fungsi atenuasi dan kondisi setempat (local site). Pada penelitian ini mencoba menganalisis besarnya nilai kurva hazard dari beberapa 
fungsi atenuasi sehingga dapat mengetahui seberapa besar pengaruh yang dihasilkan.

\section{Tujuan}

Penelitian ini bertujuan untuk menganalisis kurva hazard pada daerah kota Waisai (Pulau Waigeo) terhadap sumber gempa berupa sesar seulimeum dengan memperhitungakan beberapa fungsi atenuasi diantaranya ; fungsi atenuasi Donovan (1972), fungsi atenuasi Esteva (1972), fungsi atenuasi Cornel (1979), Campbell (1990), dan Xiang \& Gao (1994).

\section{Metode}

Refensi dalam penelitian ini mengikuti Widodo (2012) dan Douglas (1991). Untuk urutan metode yang digunakan dalam penelitian ini adalah sebagai berikut:

a. Mengidentifikasi koordinat kota Waisai (Pulau Waigeo) dan sesar Seulimeum

b. Menganalisis jarak terdekat dari sesar Seulimeum ke Kota Waisai (Pulau Waigeo)

c. Menganalisis paremeter dan fungsi Atenuasi dari setiap persamaan.

d. Menganalisis kala ulang gempa bumi yang akan terjadi.

e. Menganalisis percepatan tanah dengan menggunakan beberapa fungsi atenuasi

f. Membuat kurva hazard hasil dari analisis.

g. Kesimpulan

\section{Analisis dan Pembahasan Identifikasi Koordinat Lokasi}

Identifikasi koordinat lokasi dilakukan untuk mengetahui lokasi penelitian yang digunakan. Dalam penelitian ini lokasi yang dimaksud adalah kota Waisai (Pulau Waigeo) dan sesar Seulimeum. Hasil identifikasi tersaji sebagai berikut:

Koordinat Kota Waisai (Pulau Waigeo) :

Longitude : $131.51 \mathrm{BT}$

Latitude : 0.54 LU
Koordinat Sesar Seulimeum:

Bagian Ujung Utara

Longitude : 95.948 BT

Latitude :5.001 LU

Bagian Ujung Selatan

Longitude : 95.315 BT

Latitude : 5.9 LU

Adapun lokasi penelitian dapat dilihat pada
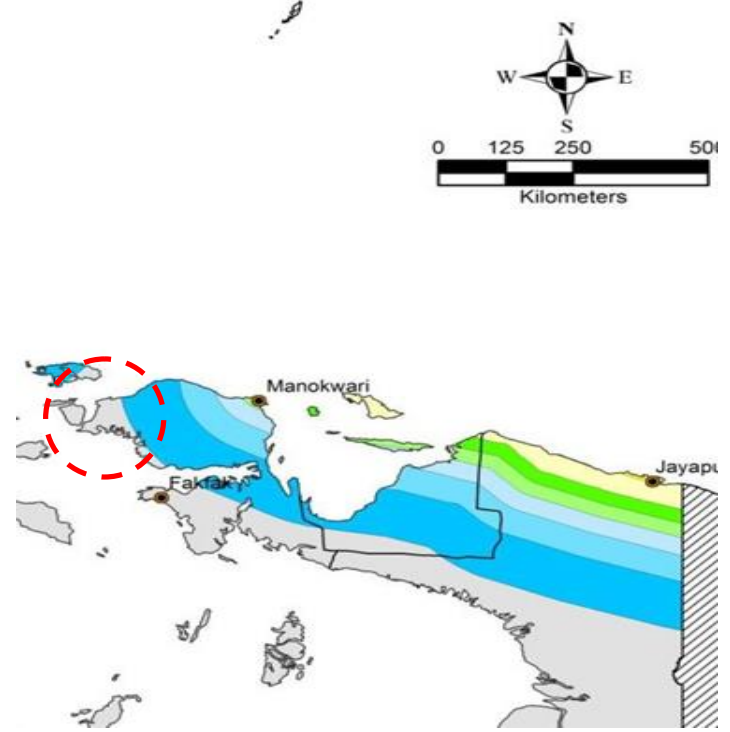

Gambar 1

Gambar 1 Lokasi Penelitian

\section{Menghitung Fungsi Atenuasi}

Fungsi atenuasi perlu diperhitungkan karena kekuatan gempa bumi berpengaruh terhadap jarak dari episenter gempa. Semakin jauh maka kecenderungan kekuatannya menurun. Walaupun terdapat beberapa kasus yang berbeda. Tetapi hal ini disebabkan oleh kondisi setempat (local site).

Dalam penelitian ini fungsi atenuasi yang digunakan adalah fungsi atenuasi McGuire (1977), fungsi atenuasi Campbell (1990), fungsi atenuasi Ambreseys (1995) dan Cornel 1979 
Fungsi Atenuasi McGuire (1977)

Perhitungan dilakukan seperti fungsi atenuasi sebelumnya. Namun memenuhi fungsi persamaan berikut.

$Y=472 \cdot 10^{0.278 \cdot \mathrm{M}} \cdot(\mathrm{R}+25)^{-1.301}$

Berdasarkan persamaan tersebut maka diperoleh kurva hazard seperti yang terlihat pada Gambar 2 berikut.

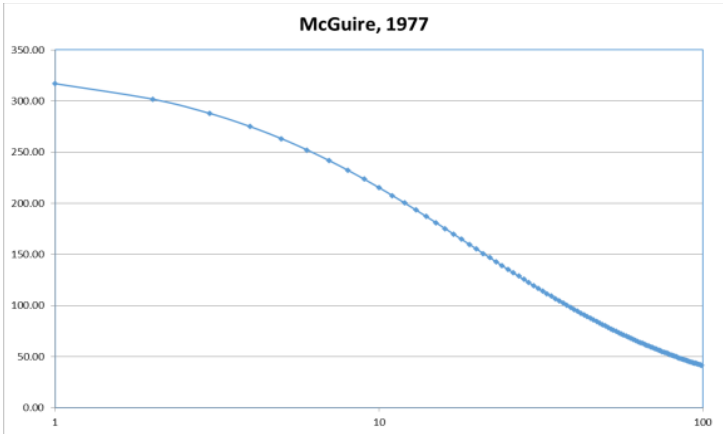

Gambar 2 Kurva Hazard dengan Atenuasi McGuire (1977)

\section{Fungsi Atenuasi Campbel (1990)} Perhitungan dilakukan seperti fungsi atenuasi sebelumnya. Namun memenuhi fungsi persamaan berikut.

$\operatorname{Ln} \mathrm{Y}=-2,245+1,09 \mathrm{M}-1,89 . \operatorname{Ln}(\mathrm{R}+0,361 . e$ 0,576.M $)+0,21 \mathrm{~S} . \mathrm{F}$ $\mathrm{F}=0$ Untuk Strike - Slip dan F $=1$ Untuk reverse

Berdasarkan persamaan tersebut maka diperoleh kurva hazard seperti yang terlihat pada Gambar 3 berikut.

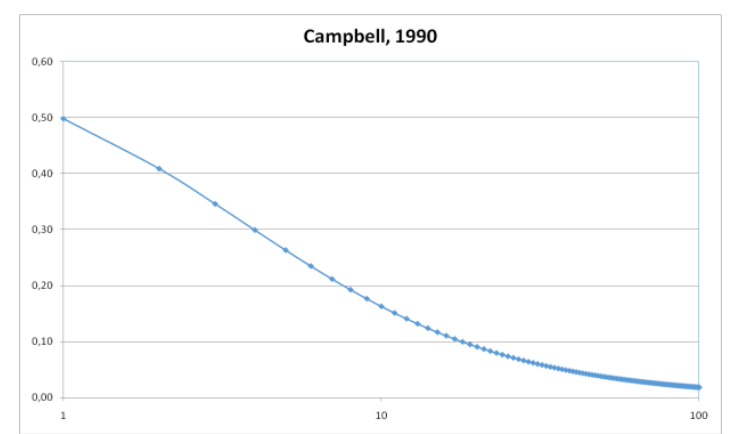

Gambar 3 Kurva Hazard dengan Atenuasi Campbell (1990)
Fungsi Atenuasi Ambraseys (1995) Perhitungan dilakukan seperti fungsi atenuasi sebelumnya. Namun memenuhi fungsi persamaan berikut.

$\log \mathrm{Y}=-1,101+0,2615 . \mathrm{Mw}-\log \mathrm{r}^{2}-0,00255 . \mathrm{r}, \quad \mathrm{r}=\left(\mathrm{R}^{2}+7,2^{2}\right)^{0,5}$

Berdasarkan persamaan tersebut maka diperoleh kurva hazard seperti yang terlihat pada Gambar 4 berikut.

Gambar 4 Kurva Hazard dengan Atenuasi Ambraseys (1995)

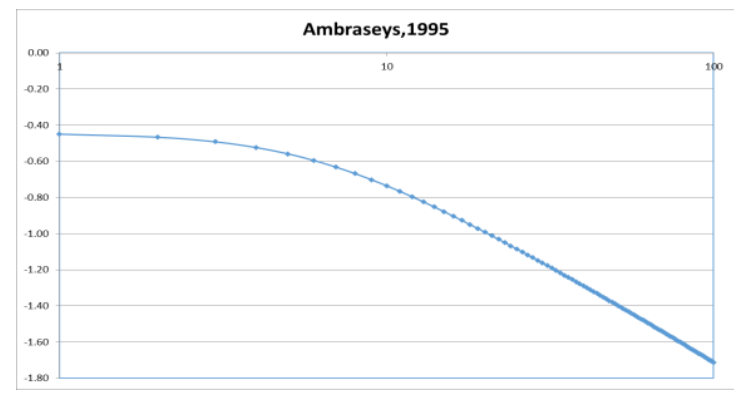

Fungsi Atenuasi Cornel 1979

Perhitungan dilakukan seperti fungsi atenuasi sebelumnya. Namun memenuhi fungsi persamaan berikut

Ln $\mathrm{Y}=6,74+0.858 . \mathrm{M} \mathrm{L}-1 . \mathrm{S} . \mathrm{Ln}(\mathrm{R}+25)$

Berdasarkan persamaan tersebut maka diperoleh kurva hazard seperti yang terlihat pada Gambar 5 berikut.

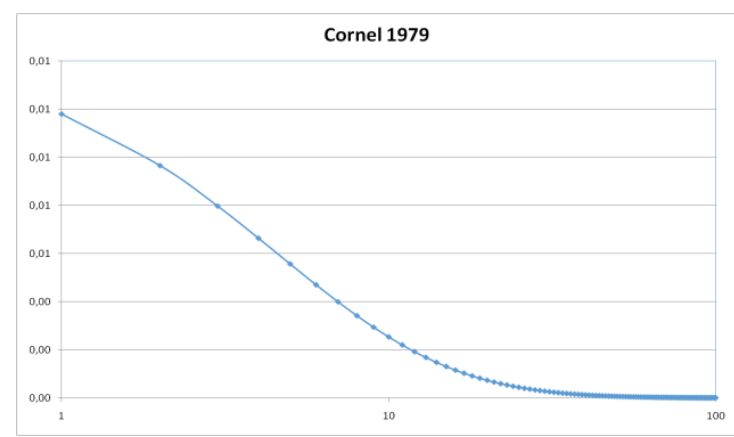

Gambar 5 Kurva Hazard dengan Atenuasi Cornel (1979) 


\section{Kesimpulan}

Berdasarkan hasil penelitian maka diperoleh beberapa kesimpulan sebagai berikut ini:

1. Besarnya nilai percepatan tanah (ground acceleration) akan meningkat seiring dengan besarnya nilai kala ulang (return period) yang diperhitungkan.

2. Kurva hazard pada daerah Waisai (Pulau Waigeo) akibat sesar Seulimeum akan menunjukkan nilai terbesar pada saat menggunakan fungsi atenuasi McGuire (1977)

3. Kurva hazard pada daerah Waisai (Pulau Waigeo) akibat sesar Seulimeum akan menunjukkan nilai terkecil pada saat menggunakan fungsi atenuasi Ambraseys (1995)

\section{Daftar pustaka}

Saputro, I. T. (2018, June 6). ANALISIS PERBANDINGAN KURVA HAZARD PADA KOTA BANDA ACEH DENGAN

SUMBER GEMPA SESAR
SEULIMEUM DAN MENGGUNAKAN BEBERAPA FUNGSI ATENUASI. https://doi.org/10.31227/osf.io/uvp2y

Campbell K. W, 1981, Near-sorce Attenuation of Peak Horizontal

Acceleration, Bulletin of the Seismological society of America, Vol.71, No.6, pp.20392070

Douglas J, 1991, A Comprehensive World-wide Summary of Strong-motion Attenuation Relationships for Peak Ground Acceleration and Spectral Coordinates, Engineering Seismology and Earthquake Engineering, Civil Engineering Department, Imperial College of Science, Technology and Medicine

Widodo, 2012, Seismologi Teknik \& Rekayasa Kegempaan, Pustaka Pelajar, Yogyakarta 